\title{
Lepidoptera of tundra habitats of the northern Kola Peninsula, Northwestern Russia
}

\author{
Mikhail V. Kozlov \& Jaakko Kullberg
}

Kozlov, M. V. \& Kullberg, J. 2008: Lepidoptera of tundra habitats of the northern Kola Peninsula, Northwestern Russia. — Entomol. Fennica 19: 114-121.

Sampling of 10 sites in 1994-2006 along roads connecting Murmansk with Teriberka and Dalniye Zelentsy yielded 140 species of moths and butterflies. Epinotia immundana and Ortholepis vacciniella are recorded for the first time from the Kola Peninsula, which increased the regional fauna to 690 species. Although some arcto-alpine species have been collected (in particular Sparganothis praecana, Catastia kistrandella, Euphydryas iduna, Glacies coracina), the fauna was clearly dominated by species typical for the forested habitats of the central part of the Kola Peninsula. This result suggests that the 'routine' sampling in north-eastern tundra between Murmansk and Ponoj might not be as important in terms of biogeography as it has been expected. Instead, new collecting trips should be oriented to areas with special vegetation, primarily limestone or sandy areas which are more likely to support more eastern and/or arctic species.

M. V. Kozlov, Section of Ecology, University of Turku, FI-20014 Turku, Finland; E-mail:mikoz@utu.fi

J. Kullberg, Zoological Museum, University of Helsinki, P.O. Box 17, FI-00014 Helsinki, Finland; E-mail: jkullber@mappi.helsinki.fi

Received 9 May 2007, accepted 11 September 2007

\section{Introduction}

The fauna of moths and butterflies of the Murmansk region is reasonably well documented, with 688 species reported to date (Kozlov \& Jalava 1994, Kozlov et al. 2000, Kozlov \& Kullberg 2006). However, the only explored locality in the north-eastern part of the Kola Peninsula, beyond the line connecting Murmansk with Pulonga (the most eastern site reached by our expedition in 2004: Kozlov \& Kullberg 2006), is the mouth of the Ponoj river. From this site Kozlov \& Jalava (1994) reported 69 species from the samples which have been collected by Finnish entomologists during the second half of the $19^{\text {th }}$ century and the beginning of the $20^{\text {th }}$ century [see Silfverberg (1988) for history]. Surprisingly, only eight species of Lepidoptera were earlier reported from the tundra and sub-tundra localities to the east of Murmansk (Kozlov \& Jalava 1994), although the road to Dalniye Zelentsy was accessible for 4WD cars already several decades ago. Quite recently 47 species were listed from the surroundings of Gavrilovo and six species - from Sem' Ostrovov archipelago (located at/near the Barents Sea shore some 115 and $175 \mathrm{~km}$ E of Murmansk, respectively) by Shutova et al. (1999).

The scarcity of the information on moths and butterflies of this region is not only the result of low accessibility, but also of harsh climatic conditions. Strong winds give almost no chance to collect moths in tundra near the Arctic Ocean, and unpredictable weather fluctuations may allow 

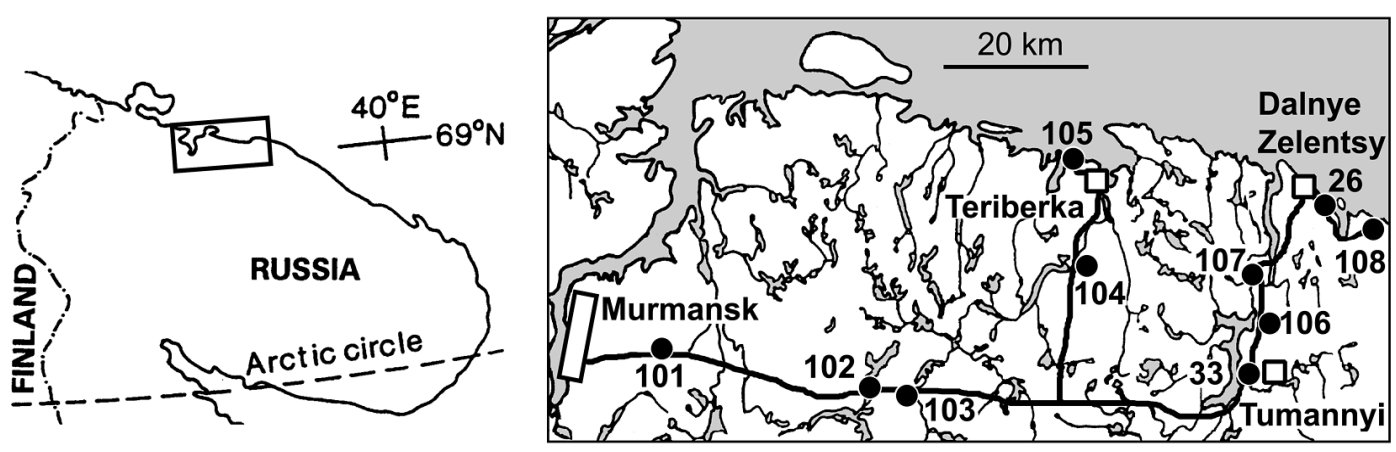

Fig. 1. Location of the study area on the Northern coast of the Kola Peninsula, north-western Russia. Enlarged view shown on right. For coordinates of sampling sites (black dots), see Table 1.

only few hours of collecting during several weeks of the stay in this area. In particular, Djakonov (1911) during two summer months of 1910 sampled only 29 species of Lepidoptera near Murmansk; similar result (31 species) for the same area was reported by Miller (1915) on the basis of two months of collecting in summer of 1914. Short trips may appear completely unsuccessful. For example, only two species of Geometridae were collected during one of the visits to Tumannyi, in spite of reasonably large collecting effort (some 10 person-hours). Still the data from the north-eastern part of the Kola Peninsula accumulated steadily since 1994, and following the very successful season of 2006 we decided to publish the complete list of species that had been discovered in tundra to the East of Murmansk.

We also include short description of the habitats, because this information, trivial for e.g. Finnish entomologists, may well be of importance for the lepidopterologists from other parts of the World. In particular, a recent description of the collecting trip to much more accessible parts of Swedish Lapland (Pickles 2005) indicates high interest to this region among researchers that have never had an opportunity to visit the tundra of Northern Fennoscandia. An additional reason for publishing this report is the current restriction of access to the seashore in the Murmansk region, which makes further collection unlikely.

\section{Materials and methods}

The road connecting Murmansk with Tumannyi was presumably built in the mid-1960ies in asso- ciation with the construction of the Serebryanskaya hydro-power plant. The first $40-50 \mathrm{~km}$ of this road near Murmansk is paved; then a reasonably good gravel road continues to both Teriberka and Tumannyi. The most distant parts of the road are accessible by 4WD cars only. In 1994-1995 it was possible to visit seashore to the North of Teriberka, as well as to drive to Dalniye Zelentsy and even further on, reaching an abandoned military camp some $7 \mathrm{~km}$ E of Dalniye Zelentsy. However, in 2001 access to both Teriberka and Dalniye Zelentsy was prohibited.

Moths and butterflies were collected by netting in several localities (Fig. 1, Table 1) during the trips to Teriberka on 10.-11.VII.1994 (54 species collected in seven sites during 17 personhours of sampling), Dalniye Zelentsy on 8.9.VII.1995 (41 species collected in six sites during 13 person-hours of sampling), and short visit of two localities between Murmansk and Tumannyi on 16.VII.2006 (30 species collected in two sites during 5 person-hours of sampling). A. Lvovsky explored surroundings of Tumannyi on 28.VI. - 17.VII.2006 (108 species collected in three sampling areas). The voucher specimens are deposited in the Zoological Museum, University of Helsinki (MZH) and in the Zoological Institute, St.Petersburg (ZIN).

We continue to use numeric codes for the localities (Fig. 1, Table 1) as in the earlier papers (Kozlov \& Jalava 1994, Kozlov et al. 2000, Kozlov \& Kullberg 2006) and add the new localities to the end of the list (numbers 101-108). Taxonomy follows Kullberg et al. (2002, 2007); asterisks $(*)$ denotes species that have not been previously reported from the Kola Peninsula. Excla- 
Table 1. Collecting localities, sampling efforts, and numbers of recorded species.

\begin{tabular}{|c|c|c|c|c|c|c|}
\hline Code & Locality $^{1}$ & $\begin{array}{l}\text { Latitude (N) } \\
\text { Longitude (E) }\end{array}$ & UTM $^{2}$ & $\begin{array}{c}\text { Years } \\
\text { sampled }\end{array}$ & $\begin{array}{l}\text { Collecting } \\
\text { effort }(h)\end{array}$ & $\begin{array}{l}\text { No. of } \\
\text { species }\end{array}$ \\
\hline 26 & Dalniye Zelentsy & $\begin{array}{l}69^{\circ} 07^{\prime} \\
36^{\circ} 04^{\prime}\end{array}$ & DS1 & 1995, 2006 & 2 & 17 \\
\hline 33 & Tumannyi & $\begin{array}{l}68^{\circ} 53^{\prime} \\
35^{\circ} 42^{\prime}\end{array}$ & XD & 1994, 1995, 2006 & 30 & 11 \\
\hline 101 & 20 km E Murmansk & $\begin{array}{l}68^{\circ} 55^{\prime} \\
33^{\circ} 38^{\prime}\end{array}$ & WB2 & 1994, 1995 & 3 & 11 \\
\hline 102 & 45 km E Murmansk & $\begin{array}{l}68^{\circ} 53^{\prime} \\
34^{\circ} 12^{\prime}\end{array}$ & WB2 & 1995, 2006 & 4 & 25 \\
\hline 103 & $50 \mathrm{~km}$ E Murmansk, at Teriberka r. & $\begin{array}{l}68^{\circ} 53^{\prime} \\
34^{\circ} 24^{\prime}\end{array}$ & WB2 & 1994, 2006 & 6 & 41 \\
\hline 104 & 20 km S Teriberka & $\begin{array}{l}69^{\circ} 01^{\prime} \\
34^{\circ} 58^{\prime}\end{array}$ & WB3 & 1994 & 2 & 13 \\
\hline 105 & 5 km NW Teriberka, sea shore & $\begin{array}{l}69^{\circ} 13^{\prime} \\
35^{\circ} 04^{\prime}\end{array}$ & WB3 & 1994 & 3 & 18 \\
\hline 106 & 12 km N Tumannyi & $\begin{array}{l}69^{\circ} 00^{\prime} \\
35^{\circ} 42^{\prime}\end{array}$ & $X D$ & 1994, 1995, 2006 & 130 & 113 \\
\hline 107 & 25 km N Tumannyi & $\begin{array}{l}69^{\circ} 06^{\prime} \\
35^{\circ} 48^{\prime}\end{array}$ & WB3 & 1994 & 5 & 29 \\
\hline 108 & 7 km SEE Dalniye Zelentsy & $\begin{array}{l}69^{\circ} 05^{\prime} \\
36^{\circ} 17^{\prime}\end{array}$ & DS1 & 1995 & 8 & 20 \\
\hline
\end{tabular}

1) Boldfaced are the locality names that can be found in The Times Atlas of the World.

2) Localities in WB2 belong to biogeographical province $L t$, in all other localities to $L$ mur.

mation mark (!) indicates confirmed record of species that had been included in the first list (Kozlov \& Jalava 1994) on the basis of earlier publications only. For collecting years, see Table 1; numbers of specimens are included for rare species only. Biogeographical provinces of Finland ( $L i, L e, L k o c, L k o r)$ are given in italics; for a map of provinces, see e. g. Kullberg et al. (2002). UTM grid for the Kola Peninsula was published by Kozlov \& Jalava (1994).

\section{Surveyed habitats and characteristic species of Lepidoptera}

\subsection{Dry tundra}

Plains and small hills in the study region are covered mostly by Empertum nigrum ssp. hermaphroditum (Hagerup) Böcher (cover 30-60\%), Cladonia spp. (30-60\%) and Vaccinium myrtillus L. (ca. 10\%); other common plants were Betula nana L., Cornus suecica L., Phyllodoce coerulea (L.) Bab., Vaccinium uliginosum L., Ledum palustre L., Arctostaphylus alpina (L.) Niedz. and Pe- dicularis lapponica L. Characteristic Lepidoptera species were Phiaris obsoletana (Zett.), Loxoterma bipunctana (F.) (extremely abundant in 104), Ancylis unguicella (L.), Zygaena exulans (Hochenw.), Colias palaeno (L.), Plebeius optilete (Knoch), Macaria fusca (Thnbg.) and Sympistis heliophila (Payk.). Seashore vegetation at 108 differed by presence of Astragalus alpinus ssp. arcticus Hultén, among which Grapholita aureolana (Tengstr.) was quite common.

\subsection{Wet tundra}

Flat areas and depressions are covered mostly by B. nana, Salix lapponum L., V. myrtillus, P. coerulea and C. suecica; other common plants were Rubus chamaemorus L., Andromeda polifolia L., Geranium sylvaticum L., V. uliginosum, Trollius europaeus L., Melampyrum pratense L., Salix myrsinifolia subsp. borealis (Fries) A. Skvorts., S. phylicifolia L., Bartsia alpina L., Sorbus aucuparia L., P. lapponica, Allium schoenoprasum ssp. sibiricum (L.) Hartman, Juniperus communis ssp. alpina (Sm.) Celak, Epilobium angustifo- 
lium L., Trientalis europaea L., Solidago virgaurea ssp. minuta (L.) Arcang., Pinguicula vulgaris L., Pyrola minor L., Eriophorum angustifolium Honck., and Carex spp. Characteristic Lepidoptera species were Incurvaria oehlmanniella (Hb.) (common in 107), Ancylis myrtillana (Tr.), Aethes deutschiana (Zett.) (most abundant in 108), Phiaris obsoletana (Zett.) (common in 26), Polopeustis altensis (Wck.) (common in 26 and 106), Udea decrepitalis (H.-S.), C. palaeno, Euphydryas iduna (Dalm.), Boloria aquilonaris (Stich.), B. freija (Thnbg.), B. frigga (Thnbg.), $P$. optilete, Erebia disa (Thnbg.), E. pandrose (Bkh.) and Diarsia mendica (F.).

\subsection{Birch woodlands}

Sparsely growing mountain birches (Betula pubescens ssp. czerepanovii (Orlova) Hämet-Ahti) occur mostly in low places, i.e. between hills and along the rivers. The birches are low $(2-5 \mathrm{~m})$, polycormic, with twisted trunks. Field layer vegetation is dominated by E. n. ssp. hermaphroditum; other common plants were J. c. ssp. alpina, S. virgaurea, M. pratense, G. sylvaticum, V. myrtillus, V. vitis-idaea L., and C. suecica; Calluna vulgaris (L.) Hull was common at 106 only. The woodlands are often associated with small bogs covered by $B$. nana, Salix glauca L., A. polifolia, $R$. chamaemorus, E. angustifolium, Caltha palustris L., V. uliginosum, Carex spp. and sometimes Dactylorhiza maculata (L.) Soó. Characteristic Lepidoptera species were Monopis spilotella (Tengstr.) (common in 107), Coleophora thulea Johansson, Sparganothis praecana (Kennel), $A$. deutschiana, A. myrtillana, Phiaris schulziana (F.), S. heliophila (very common in 103), Rheumaptera subhastata (Nolcken), Xanthorhoe montanata (Den. et Schiff.) and X. fluctuata (L.).

\subsection{Secondary vegetation along roads and on meadows near settlements}

The most typical plant species was E. angustifolium; other plants include Vicia spp., Campanula sp., Antennaria dioica (L.) Gaertn., S. v. ssp. minuta, and different grasses. Characteristic Lepidoptera species were Mompha idaei (Z.), Platyp- tilia calodactyla (Den. et Schiff.), Hellinsia osteodactyla (Z.), Gesneria centuriella (Den. et Schiff.), Lycaena phlaeas (L.), Plebeius idas (L.) and P. icarus (Rott.). Pieris napi (L.) and Plutella xylostella (L.) were collected from these habitats only.

\section{List of species}

Micropterigidae

Micropterix aureatella (Scop.). 102 (common).

Nepticulidae

Ectoedemia minimella (Zett.). 26.

Adelidae

Nemophora bellela (Wlk.). 106.

Incurvariidae

Incurvaria oehlmanniella (Hb.). 26, 103, 107

(common).

Incurvaria vetulella (Zett.). 101, 106.

Incurvaria circulella (Zett.). 106, 108.

Tineidae

Haplotinea insectella (F.). 106.

Tineola bisselliella (Hummel). 33 (within a building).

Monopis laevigella (Den. et Schiff.). 106.

Monopis spilotella (Tengstr.). 107 (common).

Gracillariidae

Parornix loganella (Stt.). 105.

Yponomeutidae

Paraswammerdamia conspersella (Tengstr.). 33, 102, 106, 107, 108.

Plutellidae

Plutella xylostella (L.). 26, 101, 102, 106, 107, 108 (common in most of the localities).

Glyphipterigidae

Glyphipterix haworthana (Steph.). 106.

Oecophoridae

Pleurota bicostella (Cl.). 105 (common), 106, 107.

Denisia stipella (L.). 105 (common), 106, 107, 108 (common). 
Elachistidae

Elachista excelsicola Braun. 106, 108.

Coleophoridae

Coleophora vacciniella H.-S. 106, 108 (common).

Coleophora glitzella Hofm. 108 (common).

Coleophora murinella Tengstr. 108.

Coleophora thulea Johansson. 103.

Coleophora virgaureae Stt. 102, 103, 106.

Coleophora striatipennella Nylander. 106.

Momphidae

Mompha idaei (Z.). 103, 105, 106.

Mompha conturbatella (Hb.). 106.

Gelechiidae

Teleiodes proximella (Hb.). 106.

Teleiopsis diffinis (Hw.). 106.

Altenia perspersella (Wck.). 106.

Chionodes lugubrellus (F.). 106.

Chionodes continuellus (Z.). 104.

Chionodes viduellus (F.). 107.

Syncopacma karvoneni (Hackman). 106: 19 ex.

1.-10.VII.2006. The northernmost record in

Russia; so far, known from the White Sea

shore only (Kozlov \& Jalava 1994).

Neofaculta infernella (H.-S.). 102, 103, 104.

Zygaenidae

Zygaena exulans (Hochenw.). 102, 103, 106.

Tortricidae

Aethes deutschiana (Zett.). 26, 33, 102, 103,

104, 106, 108 (common in most of the loca-

lities).

Aethes smeathmanniana (F.). 106 (common).

Aethes dubitana (Hb.). 26, 106.

Eana osseana (Scop.). 102.

!Eana argentana (Cl.). 106: 1 ex. 16.VII.2006.

The first confirmation of the occurrence in

the Kola Peninsula. The species was mentio-

ned in our first list (Kozlov \& Jalava 1994)

on the basis of the unpublished data by J.

Tengström referring to Lapponia Rossica, a

territory that includes not only the larger part of the Murmansk region but also the Republic of Karelia to the North of the Kem' River (Tengström 1869).

Choristoneura albaniana (Wlk.). 26, 106.
Lozotaenia forsterana (F.). 101, 102, 103, 106, 107, 108.

Aphelia viburnana (Den. et Schiff.). 26, 105.

Sparganothis rubicundana (H.-S.). 102, 103

(common).

Sparganothis praecana (Kennel). 103, 106.

Eulia ministrana (L.). 105, 106, 107.

Hedya atropunctana (Zett.). 106.

Apotomis boreana Krogerus. 102, 106.

Apotomis sororculana (Zett.). 101, 106, 107.

Apotomis sauciana (Fröl.). 102, 106 (common), 107, 108.

Olethreutes concretanus (Wck.). 101.

Olethreutes ledianus (L.). 103, 107.

Loxoterma lacunana (Den et Schiff.). 26, 102, 106.

Loxoterma bipunctana (F.). 104, 105, 106, 107 (common).

Phiaris obsoletana (Zett.). 26, 102, 103, 104, $105,106,107,108$ (common in most of the localities).

Phiaris schulziana (F.). 26, 33, 102, 103, 104, $105,106,107,108$ (common in most of the localities).

Phiaris septentrionana (Curt.). 102, 103, 104, 106 (common in most of the localities).

Phiaris turfosana (H.-S.). 26, 33, 101, 102, 106, 107.

Ancylis unguicella (L.). 26, 103, 106.

Ancylis uncella (Den. et Schiff.). 106.

Ancylis myrtillana (Tr.). 33, 101, 102, 103, 104, $105,106,107,108$ (common in most of the localities).

Eriopsela quadrana (Hb.). 33, 106, 107.

*Epinotia immundana (F. v. R.). 106: 1 ex. 3.VII.2006. The northernmost record in Finland is from $\mathrm{Li}$ (Kullberg et al. 2002).

Epinotia tetraquetrana (Hw.). 33, 102, 103, 104, 106 (common in most of the localities).

Epinotia cruciana (L.). 103.

Eucosma suomiana (Hoffm.). 106: 2 exx. 13.16.VII.2006. So far, reported from the White Sea shore only (Kozlov \& Jalava 1994).

Grapholita aureolana (Tengstr.). 26, 33, 106, 108.

Pammene clanculana (Tengstr.). 106.

Dichrorampha obscuratana (Wolff). 106: 1 ex. 15.VII.2006. So far, reported from the White Sea shore only (Kozlov \& Jalava 1994). 
Epermeniidae

Phaulernis fulviguttella (Z.). 106 (common).

Pterophoridae

Platyptilia calodactyla (Den. et Schiff.). 103, 106 (common).

Stenoptilia veronicae Karv. 102: 1 ex.

16.VII.2006. So far, reported from the White

Sea shore only (Kozlov et al. 2000).

Hellinsia osteodactyla (Z.). 103, 106 (common).

Hellinsia tephradactyla (Hb.). 106.

Pyralidae

*Ortholepis vacciniella (Lienig et Z.). 103: 1

ex. 16.VII.2006. An expected species, which is found in all provinces of Northern Finland (Kullberg et al. 2002).

Catastia kistrandella Opheim. 106: 2 exx.

3.VII.2006. The northernmost record; earlier reported from alpine habitats of the Khibiny Mts. and Lovozero Mts. (Kozlov \& Jalava 1994); also found at Krasnyi Kamen in Polar Ural (J. Kullberg, pers. obs.).

Polopeustis altensis (Wck.). 26, 106 (common). Episcythrastis tetricella (Den. et Schiff.). 104.

Gesneria centuriella (Den. et Schiff.). 104, 106 (common), 107.

Eudonia murana (Curt.). 106, 108.

Eudonia alpina (Curt.). 103.

Catoptria maculalis (Zett.). 103, 106.

Crambus ericellus (Hb.). 106.

Crambus hamellus (Thnbg.). 106.

Udea inquinatalis (Lienig et Z.). 26, 101, 103, $104,105,106,108$ (common in most of the localities).

Udea decrepitalis (H.-S.). 33, 106 (common).

Opsibotys fuscalis (Den. et Schiff.). 106.

Anania funebris (Ström). 103, 106 (common).

Hesperiidae

Pyrgus centaureae (Rambur). 106.

Pieridae

Anthocharis cardamines (L.). 106.

Pieris napi (L.). 106.

Colias palaeno (L.). 102, 103, 106 (common).

Lycaenidae

Callophrys rubi (L.). 106.

Lycaena phlaeas (L.). 106 (common).
Plebeius idas (L.). 106.

Plebeius optilete (Knoch). 102, 103, 106 (common).

Plebeius icarus (Rott.). 106 (common on meadows in the valley of the Voronja river).

Nymphalidae

Boloria eunomia (Esp.). 106 (on bogs).

Boloria euphrosyne (L.). 102, 103.

Boloria selene (Den. \& Schiff.). 106 (on bogs).

Boloria freija (Thnbg.). 103 (common), 104, 106 (common on bogs).

Boloria polaris (Boisd.). 106 (in tundra).

Boloria frigga (Thnbg.). 103 (common), 106 (on bogs).

Boloria aquilonaris (Stich.). 106 (on bogs).

Euphydryas iduna (Dalm.). 103 (common), 106 (on bogs).

Erebia disa (Thnbg.). 106, 107.

Erebia pandrose (Bkh.). 103, 106, 108 (common in all localities).

Geometridae

Jodis putata (L.). 106.

Scopula ternata (Schrank). 102, 103, 106, 107.

Xanthorhoe decoloraria (Esp.). 106.

Xanthorhoe fluctuata (L.). 103, 105.

Xanthorhoe annotinata (Zett.). 101.

Xanthorhoe montanata (Den. et Schiff.). 103, 105, 106 (common), 107.

Xanthorhoe spadicearia (Den. et Schiff.). 106.

Xanthorhoe ferrugata (Cl.). 106.

Xanthorhoe abrasaria (H.-S.). 103, 106.

Entephria caesiata (Den. et Schiff.). 105.

Spargania luctuata (Den. \& Schiff.). 33, 106 (common).

Dysstroma truncatum (Hufn.). 106.

Hydriomena ruberata (Freyer). 106.

Rheumaptera subhastata (Nolcken). 101, 103, 106 (common), 107.

Perizoma blandiatum (Den. et Schiff.). 106 (common).

Perizoma albulatum (Den. et Schiff.). 105, 106 (common).

Eupithecia pygmaeata (Hb.). 106.

Eupithecia intricata (Zett.). 106.

Eupithecia satyrata (Hb.). 106.

Eupithecia gelidata Möschl. 103, 105, 106 (common), 107.

Macaria brunneata (Thnbg.). 106. 
Macaria fusca (Thnbg.). 102, 103, 106, 107.

Macaria carbonaria (Cl.). 106.

Elophos vittaria (Thnbg.). 26, 105, 106, 107, 108 (common in most of the localities).

Glacies coracina (Esp.). 26, 106 (common in tundra), 107, 108.

Lymantriidae

Leucoma salicis (L.). 106.

Arctiidae

Phragmatobia fuliginosa (L.). 103.

Noctuidae

Autographa gamma (L.). 106 (river valley).

Syngrapha parilis (Hb.). 106 (river valley).

Sympistis heliophila (Payk.). 101, 103, 106

(common in tundra).

Sympistis lapponica (Thnbg.). 106 (tundra).

Hadula melanopa (Thnbg.). 106 (tundra).

Diarsia mendica (F.). 105, 106 (common), 107. Xestia quieta (Hb.). 106 (tundra).

\section{Discussion}

The fauna of the explored habitats resembles that of the more southern, forested part of the Murmansk region. This result is in the line with recent publication by Mikkola (2006) who found that the Lepidopteran fauna of the Norwegian coast of the Arctic Ocean was unexpectedly poor in terms of subarctic and arctic species. Two species new for the Kola Peninsula, Epinotia immundana and Ortholepis vacciniella, are also the typical representatives of the boreal fauna. This result suggests that the 'routine' sampling in north-eastern tundra between Murmansk and Ponoj might not be as important in terms of biogeography as it has been expected. However, many interesting species come close to the research area, including butterfly species such as Erebia rossii (Curt.) and E. fasciata ssp. semo (Gr.-Gr.) that are reported from the neighbouring Kanin Peninsula and the Kolgujev Island (Gorbunov 2001). Keeping in mind that many arctic species often show extremely local distributions, new collecting trips should be oriented to areas with special vegetation, primarily to limestone or sandy areas, and to meandering riversides with flowering meadows.
The recent collecting increased the number of records (compared to the data published by Kozlov \& Jalava 1994) in the UTM square WB2 from 7 to 53, in WB3 from 3 to 43, in XD from 2 to 113 , and in DS from 3 to 30 . Adding the data by Shutova et al. (1999) further increased the number of records in WB3 to 71, and in DS2 to seven. Still this area remains less explored than the central part of the Kola Peninsula (in particular in respect of leafminers, as well as early and late season species), and therefore any conclusion on the diversity of moths and butterflies of tundra adjacent to the Barents Sea would be premature.

Although most of the species collected near the Arctic Ocean are typical forest Lepidoptera, we have no reasons to conclude that all species inhabiting the central (forested) part of the Kola Peninsula can be found in tundra near the Barents Sea shore. Moreover, surprisingly high overlap (65 species) between the lists of 94 species published by Mikkola (2006) and of 140 species included in the present paper hints that we can hardly expect to substantially increase the number of the species by further collecting in tundra habitats. Thus, it seems likely that the fauna of moths and butterflies of tundra near the Arctic Ocean is just a fraction of the fauna typical for the forested parts of the Northern Fennoscandia, with only a few arctic species added. However, more data are necessary to test the hypothesis that some specific life history traits determine the ability of certain forest species to inhabit the tundra biome.

Quite predictably, diversity of Lepidoptera increased with the diversity of vegetation, with the maximum number of species occurring in the river valleys. Comparable number of species was collected in bogs surrounded by birch woodlands, while only a few species were recorded from dry tundra. However, these observations may be partly biased by microclimate: more sheltered habitats allow easier collection of moths and butterflies than does the flat and windy tundra.

Although no quantitative estimates of species' abundances had been performed, we got the strong impression that a vast majority of species in tundra was either common or rare, with almost no species demonstrating intermediate (moderate) abundance. This clearly contradicts observations conducted in the forested parts of the Kola Peninsula, where both common and rare species 
represent relatively minor parts of the species pool.

The knowledge on the fauna of moths and butterflies of the Kola Peninsula, with 690 species recorded so far, is now approaching the level of Northern Fennoscandia. Still the comparison with the Northern Finland (biogeographical provinces $L e, L i, L k o c$ and $L k o r$ ), with 984 species of moths and butterflies recorded by the end of 2006 (Kullberg et al. 2007), suggests that some 250 300 additional species of Lepidoptera will certainly be found in the Kola Peninsula.

Acknowledgements. We are thankful to A. Lvovsky, V. Zverev and E. Melnikov for collecting of Lepidoptera, to the late J. Jalava, as well as to L. Kaila, A. Lvovsky, A. Matov and V. Mironov for identification of difficult taxa, and to K. Mikkola for comments on an earlier draft of the manuscript. The travel was partially supported by the Academy of Finland.

\section{References}

Djakonov, A. M. 1911: Notes on the Lepidoptera of the Murmansk coast. - Russian Entomol. Review 11: 13-17. [In Russian].

Gorbunov, P. Y. 2001: The butterflies of Russia: Classification, genitalia, keys for identification. - "Thesis", Ekaterinburg. 320 p.

Kozlov, M. V. \& Jalava, J. 1994: Lepidoptera of the Kola
Peninsula, Northwestern Russia. — Entomol. Fennica 5: $65-85$.

Kozlov, M. V. \& Kullberg, J. 2006: Lepidoptera of Terskij seashore of the Kola Peninsula, Northwestern Russia. — Entomol. Fennica 17: 123-129.

Kozlov, M. V., Jalava, J. \& Shutova, E. 2000: New records of Lepidoptera from the Kola Peninsula, Northwestern Russia. - Entomol. Fennica 11: 131-136.

Kullberg, J., Albrecht, A., Kaila, L. \& Varis, V. 2002: Checklist of Finnish Lepidoptera - Suomen perhosten luettelo. - Sahlbergia 6: 45-190.

Kullberg, J., Albrecht, A., Kaila, L. \& Varis, V. 2007: Checklist of Finnish Lepidoptera - Suomen perhosten luettelo. [www document]. URL http:// www.fmnh.helsinki.fi/elainmuseo/hyonteiset/perhoset/index.htm (Accessed 20 April, 2007).

Mikkola, K. 2006: On the Lepidopteran fauna of the Norwegian coast of the Arctic Ocean. - Baptria 31: 94 99. [In Finnish].

Miller, E. 1915: On the characteristics of the lepidopteran fauna of the Murmansk coast. - Bull. Soc. Entomol. Moscow 1: 124-135. [In Russian].

Pickles, A. J. 2005: Collecting in Lapland, June and July 2004. — Entomol. Rec. J. Var. 117: 207-220.

Shutova, E. V., Antonova, E. M., Sviridov, A. V. \& Kutenkova, N. N. 1999: Lepidoptera of the Kandalaksha reserve. (Flora and Fauna of Nature Reserves, 80). Commission of the Russian Academy of Sciences on Nature Reserves, Moscow. 48 p. [In Russian].

Silfverberg, H. 1988: Finnish entomologists on the Kola Peninsula. - Notulae Entomol. 68: 115-120.

Tengström, J. M. J. af. 1869: Catalogus Lepidopterorum faunae Fennicae praecursorius. - Notiser ur Sällskapets pro Fauna och Flora Fennica Forhandlingar 10: $287-371$ 